\title{
Nutritional Taboos among the Fullas in Upper River Region, The Gambia
}

\author{
Guillermo Martínez Pérez ${ }^{1}$ and Anna Pascual García ${ }^{2}$ \\ ${ }^{1}$ Department of Physiatrics and Nursing, Faculty of Health Sciences, University of Zaragoza, C/Domingo Miral $s / n$, \\ 50009 Zaragoza, Spain \\ ${ }^{2}$ University of Barcelona, 08007 Barcelona, Spain \\ Correspondence should be addressed to Guillermo Martínez Pérez; gmartinezgabas@gmail.com
}

Received 24 April 2013; Revised 6 July 2013; Accepted 7 July 2013

Academic Editor: Kaushik Bose

Copyright (C) 2013 G. Martínez Pérez and A. Pascual García. This is an open access article distributed under the Creative Commons Attribution License, which permits unrestricted use, distribution, and reproduction in any medium, provided the original work is properly cited.

\begin{abstract}
Malnutrition is one of the leading causes of morbidity and mortality of children in the world. In The Gambia, malnutrition is one of the major public health problems. Among the factors determining its high prevalence, cultural norms play a crucial role. Food taboos influence the amount, frequency, and quality of nutrients that mothers and children consume. In this qualitative study carried out in the Upper River Region, The Gambia, seventeen mothers whose ethnic affiliation is Fulla were interviewed. The objective was to describe their food taboos and how they influence their nutritional health. The findings of this study demonstrate that some of the taboos practiced by the Fulla may be regarded as contributing factors to protein-energy malnutrition in children and pregnant and lactating women. The findings will inform the design of future health education strategies targeting malnutrition in this specific cultural context.
\end{abstract}

\section{Introduction}

Malnutrition in children under-five living in developing countries is one of the major leading causes of disease and mortality $[1,2]$. It leads to long-term consequences such as impaired cognitive development, growth impairment, and poor academic performance [3].

The Gambia is the smallest country in West Africa, lying along $400 \mathrm{~km}$ from the Atlantic Ocean to the east, following the shores of the River Gambia. One million three hundred sixty four thousand people inhabit this small republic according to the 2003 census [4]. The Gambia is one of the poorest countries in the world, ranking 165 in the Human Development Index of UNDP [5]. The infant mortality rate accounts for 103 per every 1000 live births [5]. The prevalence of under-fives suffering from underweight is $18 \%$, while $10 \%$ of under-fives are suffering from wasting and $24 \%$ from stunting (2007-2011 according to UNICEF) [6]. A case fatality of $22.7 \%$ was found in severely malnourished children admitted in hospital facilities [7].

Most of the Gambians have their tribal affiliation within the following ethnic groups: Fulla, Jolla, Mandinka, Manjago,
Sarahulle, Serere, and Wolof [8]. The Fulla form the majority in the Upper River Region (URR), the eastern most administrative department of the country and where this present study was implemented. Traditionally, the Fulla are nomadic cowherds. They dwell in villages for the most part of the year and leave their settlements for about 4 months, when they go shepherding. It is only recently that they are becoming increasingly sedentary and adopting other incomegenerating activities. The men have the role of cattle-breeding [9]. The women are responsible for upbringing the children and for the farm work and routine household chores. Men do not help them $[3,10]$. Due to the extenuating work that women often endure while attending the farms they have to leave their children at home with their grandmothers, who will take care of their nutritional and educational needs $[3,11,12]$.

Cultural norms, taboos, and beliefs lie within the contextual factors included in the stratum basic causes of malnutrition according to the categorization established in the UNICEF Food-Care Health conceptual framework [10, 13]. It is assumed that taboos, customs, and beliefs contribute to malnutrition among the Fulla in different ways [3]. 
(i) Interrupting the growth of children to the point of death or disability-for example, colostrum is not given to many newborn babies, who are instead fed on water with sugar or water with milk during their first days of life [12].

(ii) Depleting the available resources for the most vulnerable members of the family-for example, as it happens in other regions of West Africa, the meals are served first to the men, who receive the largest share of the family foods $[3,10,14]$.

(iii) Breeding social stigma-for example, Fulla do not eat food cooked by a noncircumcised woman [8].

There is a gap in the literature on food taboos among the Fulla in The Gambia. In a different setting, in Nigeria, a high level of malnutrition-38.7\%—was observed among settled Fulla children [9]. Poverty, lack of education, changes in migratory tendencies, and the survival of certain beliefs and taboos are all factors leading to malnutrition in Nigerian Fulla. These factors can also be seen among the Fulla in The Gambia. Other studies that describe the causes of malnutrition among the Mandinka in The Gambia-in the URR, Fulla and Mandinka often dwell in the same settlements and interbreeding marriage happens between both ethnic groups - help us to understand the constraints and difficulties that the Fulla endure to have access to a healthy and balanced diet $[3,11,12]$.

1.1. Purpose. The goal of this study is to describe the food taboos that could potentially affect the nutritional status and health of the children and mothers of the Fulla ethnic group in the Upper River Region, The Gambia.

Health education has been identified as one of the main components in strategies to promoting behavioural changes aiming to improve the nutrition status of mothers and children. Understanding food taboos among the Fulla, the purpose of this work, can inform the design of more efficient health education interventions targeting malnutrition in this definite cultural context $[3,9]$.

\section{Materials and Methods}

2.1. Study Site. The study was implemented in three villages surrounding Basse, the capital of the URR. The villages were Mansajang Kunda, Wally Bah, and Bassending. These villages were randomly selected from a preconfigured list of villages that lay within $50 \mathrm{~km}$ distance from Basse, were accessible by road, and had their population mainly composed by Fulla.

2.2. Data Collection Methods. The methods chosen were a review of the literature, a focus group discussion (FGD), and a semistructured questionnaire. The literature review was designed to search for studies on nutritional taboos among the different ethnic groups inhabiting Sub-Saharan African countries, with a special focus on the Fulla living in The Gambia.
The FGD was chosen as a research tool helpful to elicit culturally relevant themes and vocabulary for use when interviewing the respondents $[3,10]$. One nurse (Manjago) and six nurse attendants (all Fulla), all with background in community management of malnutrition, were identified to take part in this FGD.

The information gathered from the review of the scarce literature on food taboos among the Fulla and the opinions of the nurses who participated in the FGD were useful to finalize a semistructured questionnaire. The first version of the questionnaire consisted of 23 items, and it was translated from English to Fulla by three of these nurse attendants, who were also trained as interviewers. The questionnaire was tested in six respondents. It was observed that four of the 23 items had to be eliminated because they may introduce bias in the study. Thus, the final questionnaire consisted of 19 items.

2.3. Sampling. Snowball sampling was the method used for the enrolment of the respondents in Mansajang Kunda, Wally Bah, and Bassending [15-17]. Sampling took place between October and December 2011. The leader of the village, or alkalo, introduced the first respondent, according to our inclusion criteria, to the interviewers. Each respondent guided the interviewers to the following respondent. Emphasis was put in the expectation that the respondents were to act as key informants; they had to be willing to speak openly of their knowledge on food taboos and to comply with the following inclusion criteria:

(i) female members of the Fulla ethnic group,

(ii) women aged above 18 years old,

(iii) mothers of at least one child under five years old,

(iv) being born and resident in the URR.

Mothers of children under-five were preferred for the purpose of this study because it was assumed that they were able to provide information from their own experience since they were making feeding choices for their own children at the time of the study [3]. The exclusion criteria were all the persons who did not comply with any of these inclusion criteria.

2.4. Ethics. The ethical expectations from research carried out in a context where the sample is illiterate and poor $[18,19]$ were that

(i) the respondents should give their informed consent;

(ii) no mental and physical harm was to be inflicted to them;

(iii) the benefits of the study were to outweigh the risks;

(iv) they were to be protected from harmful side effects.

All the communication between the respondents and the interviewers took place in Fulla language. When first meeting the mothers, the purpose of the study was explained and then a verbal consent for being interviewed was requested. 
2.5. Analysis. The interviewers prepared the transcripts and their translations into English. Thematic framework approach guided the analysis of the transcripts [3, 10]. This involved going through the texts identifying emerging themes by both principal investigators separately. When no more emerging themes were identified, data saturation was considered to be achieved, and no more interviews were carried out. After individual analysis, all these concepts were shared. Validity and reliability was ensured by triangulation of the results gathered from the interviews with the information obtained at the FGD, by having these data doublechecked by the two principal investigators separately, and, afterwards, by sharing the results with the FGD attendants [17].

\section{Results}

Seventeen Fulla women were interviewed between November and December 2011. Gender, age, number of parity and cowives, education, ethnic group, and religion were the basic demographics collected. All the respondents were Muslim. The mean age of the mothers was 41 years. The mean parity was 6,3 children. Twelve mothers were illiterate, three had attended primary school, and two mothers had attended secondary school.

The authors identified six main common areas of knowledge. There was a general trend among the mothers to mention certain types of food as taboos, but, when asked about the meaning behind this, no clear explanation was provided. Commonly, the concept of nutritional taboo was connected to what the Fulla are not allowed to eat, either because their parents did not eat it or because eating it can lead to health problems.

JB (45 years old): Nutritional taboos is that we do not eat crocodile, monkey, pork or lizards. We found that our elders did not eat them, and if we eat them we will have skin disease.

Some mothers related the concept of taboo with what they should not eat during pregnancy.

FD ( $<20$ years old): What I understand for a nutritional taboo is that a pregnant woman does not eat the head of a goat because they say it will have the child to have hair in his stomach.

3.1. Taboos during Pregnancy and Breastfeeding. The respondents identified various types of food that were not to be eaten because it was believed that they could affect the newborns' health, prolong labour, or provoke other health problems to the mother (Table 1). The most mentioned were catfish (by 11 mothers), pepper [10], bread [9], bitter tomato [8], egg [7], and banana [6]. Other foods mentioned were millet [4], sorrel, partridges [3], groundnut, mango, baobab, beef, goat [2], salt, crocodile, warthog, squirrels, lime, and guinea fowl [1].

On catfish, the most extended belief was that if catfish were eaten during pregnancy, the mother would give birth to a flaccid, sloppy, dribbling child.
TABLE 1: Number of times taboos during pregnancy were mentioned by the respondents.

\begin{tabular}{|c|c|c|c|}
\hline \multicolumn{4}{|c|}{ Type of food taboos during pregnancy } \\
\hline Main source of & Food group & Type & No. of times \\
\hline \multirow{3}{*}{ Carbohydrates } & \multirow{3}{*}{ Cereals } & Millet & 4 \\
\hline & & Groundnut & 2 \\
\hline & & Bread & 9 \\
\hline \multirow{6}{*}{ Vitamins (Vit A \& C) } & \multirow{2}{*}{ Legumes } & Bitter tomato & 8 \\
\hline & & Pepper & 10 \\
\hline & \multirow{4}{*}{ Fruits } & Banana & 6 \\
\hline & & Lime & 1 \\
\hline & & Mango & 2 \\
\hline & & Baobab & 2 \\
\hline Iodine & Seasoning & Salt & 1 \\
\hline Iron & Green leaf & Sorrel & 3 \\
\hline \multirow{9}{*}{ Animal proteins } & Egg & Egg & 7 \\
\hline & \multirow{2}{*}{ Birds } & Partridges & 3 \\
\hline & & Guinea fowl & 1 \\
\hline & Rodents & Squirrels & 1 \\
\hline & Fish & Catfish & 11 \\
\hline & \multirow{3}{*}{ Mammals } & Beef & 2 \\
\hline & & Goat & 2 \\
\hline & & Warthog & 1 \\
\hline & Reptiles & Crocodile & 1 \\
\hline
\end{tabular}

MS (60 years old): The child may salivate a lot or the child may be floppy. And people ask you, what is wrong? Did you eat catfish?

If pepper or bitter tomato was eaten during pregnancy, the newborn baby may have skin problems-such as skin rash or pimples_or the baby may be very irritable.

BC (35 years old): When a pregnant eats bitter tomato, the child will have pimples. What is the treatment for the pimples? You soak the seeds into water and then you bath the child. The same with pepper.

Eating bread, as well as banana, millet, or groundnut, may lead to problems in labour.

MS (60 years old): A pregnant woman, few months before delivery, should not eat bread because it will make the baby big in the stomach and the labour would be difficult.

If eggs are eaten during pregnancy, the child may be mute, dumb, or stuttering. Other foods mentioned were sorrel, partridge, mango, baobab, beef, goat, salt, lime, crocodile, and guinea fowl. Sorrel, for instance, a green leaf plant that is rich in iron content, was believed to debilitate the pregnant mother.

JB (28 years old): Sour things, like sorrel, lime, should not be eaten if you are pregnant. It reduces your haemoglobin. 
If the pregnant mother ate goat, baobab, or crocodile, the belief is that the child could acquire some typical characteristics of these foods. The mothers explained the risk of a metamorphosis as follows:

$\mathrm{NB}$ (53 years old): When we are pregnant we do not eat crocodile because the baby will be lazy like a crocodile, and he will have difficulties on walking.

HK (23 years old): If a Fulla woman is pregnant should not eat baobab because the child skin would not be smooth. The stomach of a goat should not be eaten by a pregnant woman because it causes wounds all over the newborn head.

DJ (45 years old): A pregnant woman should not eat cow. The child will be fat. But later on the child will have copper hair and loss of weight. Also should not eat ram, goat or cow's leather because your child will have copper hair as well.

In addition, the respondents were asked if the Fulla gave colostrum to the newborn. All of them answered affirmatively. No taboos were described when asked about the foods they should not eat themselves or provide to the child during breastfeeding or when introducing weaning foods. The exception was one mother who mentioned sorrel.

FD ( $<20$ years old): A breastfeeding woman should not take sorrel because it has no vitamins.

3.2. Taboos during Disease. Some mothers coincided in pointing out foods considered taboos when the Fulla are suffering from malaria or pneumonia and having fever, coughing, vomiting, or diarrhoea as symptoms (Table 2). These taboos were not thoroughly explained by the respondents. Most commonly, the belief was that there were not food taboos connected to diseases.

Millet was mentioned by five mothers. Four mothers mentioned groundnut, sorrel, sour milk, and cooking oil. Three mentioned pepper, cow milk, and green leaf plants. Mango and rice were mentioned twice. Beans, baobab, and salt were mentioned only once.

When suffering from malaria, having milk, sour milk, mango, vegetable oil, or sorrel is not recommended. One respondent said that, if a Fulla has pneumonia, he/she should not eat food from the previous day.

The mothers were asked about food taboos related with specific symptoms, regardless of the disease. If the person who is ill has diarrhoea, then milk, sour milk, pepper, or oil should not be eaten. If that person is coughing, then groundnut, oil, or couscous should not be eaten. If that person is vomiting, he or she should not eat the neither the leftovers from the previous day nor pepper or cold water. If the person has fever, he/she should not drink hot water, milk, or sour milk.

FD ( $<20$ years old): You should not eat mango (if you have malaria). You do not eat pepper (if diarrhoea). Pneumonia I do not know. You do not eat pepper (if vomiting). Some will tell you if you have cough you should not eat groundnut.
TABLE 2: Number of times that taboos during disease were mentioned by the respondents.

\begin{tabular}{lccc}
\hline \multicolumn{3}{c}{ Type of food taboos during disease } \\
Main source of & Food group & Type & No. of times \\
\hline \multirow{2}{*}{ Carbohydrates } & Cereals & Millet & 5 \\
& & Groundnut & 4 \\
& & Rice & 2 \\
\hline Lipids & Oil & Cooking Oil & 4 \\
\hline \multirow{2}{*}{ Vitamins (Vit A \& C) } & \multirow{2}{*}{ Fruits } & Pepper & 3 \\
& & Bango & 2 \\
Iodine & Seasoning & Salt & 1 \\
\hline \multirow{2}{*}{ Calcium \& Proteins } & \multirow{2}{*}{ Dairies } & Cow milk & 3 \\
& & Sour milk & 4 \\
\hline \multirow{2}{*}{ Iron } & Legumes & Beans & 1 \\
& Green leaf & Sorrel & 4 \\
\hline
\end{tabular}

JB (45 years old): Vegetable oil should not be eaten (if malaria). If diarrhoea, vegetable oil should not be given. If pneumonia or vomiting, I do not know. If coughing, should not be given vegetable oil.

The reason why eating sorrel while being sick is a taboo is similar to the reasons expressed while being pregnant or during breastfeeding.

FD (<20 years old): If you are sick you do not know if you have enough blood, and if you take sorrel you lose more blood.

3.3. Food Taboos Related with Circumcision. Both girls and boys are circumcised in The Gambia, and, after having undergone circumcision, there are certain foods that they should not consume (Table 3). Fourteen respondents agreed that they should not eat pepper following a circumcision ceremony. Other respondents added that they should not eat groundnut [7], bitter tomato [3], sour milk [2], lime, cow milk, salt, sorrel, and beef [1]. While most of the taboos were not explained, there was a general consensus in agreeing that, if pepper was used, the circumcised would suffer from pain when passing urine or the healing process would last longer.

JB (36 years old): They will not chew groundnut, and they will not eat pepper. They say like if they eat that the circumcised are not going to cure very easily.

Pepper should also not be used in other types of ceremonies [8] such as when tying a marriage or at naming ceremonies, weddings or funerals. Pepper is connected with devils, problems, and fights.

HK (23 years old): Like when a man is getting married, the wife's family comes to the future husband house, the mother should not cook with pepper because it may not be agreements.

Some people refuse to eat food that has been cooked by a noncircumcised woman [8]. The respondents were asked 
TABLE 3: Number of times that taboos related with circumcision were mentioned by the respondents.

\begin{tabular}{lccc}
\hline \multicolumn{3}{c}{ Type of food taboos related with circumcision } \\
Main source of & Food group & Type & No. of times \\
\hline Carbohydrates & Cereals & Groundnut & 7 \\
& Legumes & Bitter tomato & 3 \\
Vitamins (Vit A \& C) & Pepper & 14 \\
& Fruits & Lime & 1 \\
\hline Iodine & Seasoning & Salt & 1 \\
\hline \multirow{2}{*}{ Calcium \& Proteins } & Dairies & Cow milk & 1 \\
& & Sour milk & 2 \\
\hline Iron & Legumes & Sorrel & 1 \\
\hline Animal proteins & Mammals & Beef & 1 \\
\hline
\end{tabular}

TABle 4: Number of times that specific taboos for the men were mentioned.

\begin{tabular}{lccc}
\hline \multicolumn{4}{c}{ Type of food taboos related with manhood } \\
Main source of & Food group & Type & No. of times \\
\hline Carbohydrates & Cereals & Corn & 1 \\
Iodine & Seasoning & Salt & 2 \\
Animal proteins & Mammals & Beef & 1 \\
\hline
\end{tabular}

about this taboo. Eight mothers said they would not eat food cooked by such person, two of them explaining that Islam forbids it. Six mothers said that they would eat it. Two said that they would if they were not aware that the cook was not circumcised. One refused to answer.

KJ (18 years old): In my area when a child is born you are circumcised. But in case you are not circumcised until when you are old and you cook food we will not eat it, the elders would not accept it.

3.4. Food Taboos Connected with Manhood. The respondents were asked whether there were food that should not be used by married men, old men, men who want to have children, or men who are preparing themselves for wrestling or battling (Table 4). The information obtained was not significant because only a few coincided in their answers. Only two respondents coincided in answering that men who want to perform well in sex should not eat salt.

The respondents were probed about food taboos existing among cattle breeders, farmers, tailors, or other professions. The mothers did not coincide in pointing out the food taboos with the professions asked, and no explanations were given.

3.5. Taboos within the Kabilahs. The Fulla are socially aggregated in family clans called kabilah in The Gambia. Each kabilah has certain types of food that are forbidden for their members to consume (Table 5). Most of the respondents identified foods but did not link their answer with the precise kabilah that was not supposed to consume them. Partridge was mentioned four times, guinea fowls and warthogs three times, and monitor lizard was mentioned twice. Lizards, wolves, Gambian rats, squirrels, ducks, and monkeys were
TABLE 5: Number of times that taboos for the kabilah were mentioned by the respondents.

\begin{tabular}{cccc}
\hline \multicolumn{3}{c}{ Type of food taboos for the kabilah } \\
Main source of & Food group & Type & No. of times \\
\hline \multirow{4}{*}{ Animal proteins } & Birds Eggs & Partridges & 4 \\
& & Guinea fowl & 3 \\
& \multirow{4}{*}{ Rodents } & Duck & 1 \\
& & Gambian rat & 1 \\
& \multirow{4}{*}{ Mammals } & Squirrel & 1 \\
& & Monkey & 1 \\
& Reptiles & Wolf & 1 \\
& & Warthog & 3 \\
& & Monitor lizard & 2 \\
\hline
\end{tabular}

mentioned only once. The reasons why they should not eat such food were not clearly explained.

HK (23 years old): There are some kabilahs that do not eat guinea fowl and some that do not eat wolf. Neither Fulberimbe do. This was before; the parents forbid eating certain things but children nowadays do not obey.

DJ (45 years old): There are some kabilahs that do not eat monitor lizard, like Mballow Kunda and Jawo Kunda. And there is a bird in the bush called gerlal (partridge), those two Kabila should not eat it.

NB (53 years old): Baldeh Kunda dont eat gerlal. When they eat it you will see pimples on the body. Kandeh do not eat birds. There is one old woman in that village she does not even like to see the feather of the birds. She does not want even to pass close to them. If she does the body will have pimples.

3.6. Other Food Taboos among the Fulla. The following food taboos that were described by the respondents are not related to any life event or specific belief (Table 6).

3.6.1. Insects. Thirteen mothers mentioned some insects as a taboo: termites [14], flying ants [9], and grasshoppers [8]. Two of them were aware that the Fulla in Guinea eat them. Insects are not eaten because their parents did not eat them.

3.6.2. Reptiles. Eleven mothers said they do not eat lizards, while two others said that lizards are only eaten when used as a traditional medical treatment, and one said that it is the children who eat them. Monitor lizard was mentioned as a taboo by seven, though other seven said that some Fulla eat it, and three said that everybody eats this animal. Being asked about crocodiles, six mentioned they do not eat it while two that some persons do eat this animal's meat.

MS (23 years old): Some use it for treatment (lizard). For child that urinates on the bed, you cook it and give him the water that was boiled into. 
TABLE 6: Number of times that taboos for the kabilah were mentioned by the respondents.

\begin{tabular}{|c|c|c|c|}
\hline \multicolumn{4}{|c|}{ General food taboos } \\
\hline Main source of & Food group & Type & No. of times \\
\hline \multirow{15}{*}{ Animal proteins } & \multirow{3}{*}{ Birds } & Vultures & 15 \\
\hline & & Partridge & 3 \\
\hline & & Duck & 2 \\
\hline & \multirow{6}{*}{ Mammals } & Monkey & 10 \\
\hline & & Horse & 13 \\
\hline & & Rabbit & 1 \\
\hline & & Donkey & 2 \\
\hline & & Warthog & 16 \\
\hline & & Hyena & 1 \\
\hline & \multirow{3}{*}{ Insects } & Flying ants & 8 \\
\hline & & Termites & 12 \\
\hline & & Grasshoppers & 6 \\
\hline & \multirow{3}{*}{ Reptiles } & Monitor & 9 \\
\hline & & Other lizards & 11 \\
\hline & & Crocodile & 8 \\
\hline
\end{tabular}

KJ (40 years old): In our tradition, some Fulla eat lizard but they eat it when they are sick, when they cough, as medicine. They cut the head and burn the body and give it to the person.

JB (36 years old): In our tradition there is a crocodile we can eat, if we have bad cough we can eat it, we make it like a soup and give it to the children.

3.6.3. Birds. Partridge was mentioned before as a taboo for the members of certain kabilah by four respondents. When asked again, twelve mothers said they eat them and five said that they do not. All of them said they do not eat vulture.

3.6.4. Mammals. Fourteen mothers said that they eat Gambian rat, while three said that some Fulla do not eat that animal. Twelve said they do not eat warthog, while five said that some eat and that some do not. Fourteen mentioned they do not eat horse. Two said that the Fulla do not eat cows, the rest of respondents answering that they do eat.

JJ (47 years old): The intestine of a cow should not be eaten if the mother has a boy, because the penis will be big. The stomach of the cow she should not eat because if she does the head of the child will have wounds. These wounds cannot be cured unless you buy stomach of the cow, put it in the child head, later remove it, cook it and the mother eats it.

Ten said that they do not eat monkey, but five said that some do eat monkey.

KJ (18 years old): [On red monkeys?] When we catch them we sell it to the Mandinka. [On black monkeys?] When we catch them we give them to the dogs. [Why you do not eat monkeys?] They resemble a human being.
With regard to the hippopotamus, one mother said that they would not eat it, seven said that some eat and some do not, and the rest said that they eat monkey. Two mentioned that the head should not be touched or mentioned even.

\section{Discussion}

In this qualitative study, it has been attempted to learn of the food taboos that could negatively affect the health of the children and pregnant and lactating women of the Fulla ethnic group. The findings can then be analysed from the perspective of how they contribute to deprive to the persons who comply with them essential nutrients. Acknowledging these taboos may inform the design of health promotion interventions aiming at improving the nutritional status of the most vulnerable members of the Fulla ethnic group in this specific sociogeographic context.

4.1. Effects on Nutrition. If followed, most of the taboos reported by the respondents of this study contribute to the depletion in the proteins and calories intake that the Fulla have throughout their life. It is to be noted that not all inhabitants of the URR comply with these taboos and that even the ones who do may be making use of other substitutes. But it should also be kept in perspective that The Gambia is one of the poorest countries in West Africa, a country that is suffering from the effects of desertification, long droughts, and man-made fires that are destroying their natural habitats and, hence, reducing the resources available. Moreover, there is evidence that the change in food types and habits observed in the Fulla that have settled down might compromise the normally high protein diet associated with their traditional pastoral lifestyle [9]. It should also be reminded that, according to UNICEF, $18 \%$ of the under-fives are suffering from malnutrition [6]. For the Fulla mothers and children who cannot afford access to nutritional supplements, respecting these taboos turns out being a contributing factor to their depletion of essential nutrients.

The respondents of this study mentioned some insects as taboo, such as grasshoppers, termites, or flying ants. Cultural barriers that prevent populations from eating insects are not uniquely seen in The Gambia. The fact is that insects are rich in protein content and have been widely recommended to supplement diets in, for instance, people living with HIV and who are at risk of suffering from protein malnutrition [20, 21]. Regardless of their protein content, the Fulla would not use them as supplements even if, as some of the respondents explained, they are aware that insects are edible because the Fulla living abroad-for example, in Guinea-consume them. Other animal sources of proteins, such as partridges, warthogs, monitor lizards, crocodiles, hippopotamus, and monkeys are also considered taboos by some Fulla. Most of these animals are affordable even for the poorest families because they are easily available in their most immediate environment [22]. Even if the Fulla are aware that these birds, reptiles, and mammals are edible, since they are regarded as taboos, they would not be consumed in many households in the Upper River Region. 


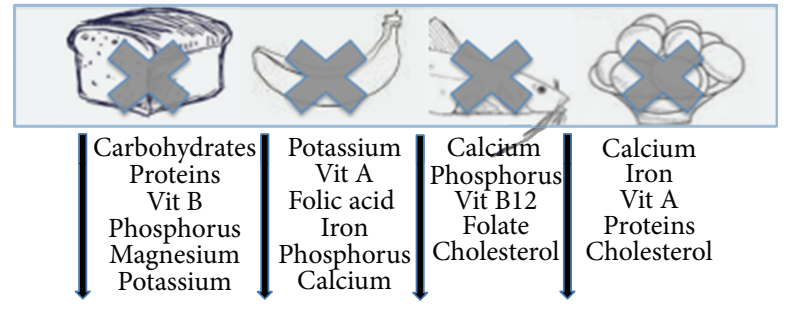

$\square$ Protein-energy depletion

FIgURE 1: To illustrate the impact of these taboos, see the following chain-reaction as an example. If bread is not eaten, the pregnant woman is reducing her intake of carbohydrates, proteins, vitamin B, phosphorus, magnesium, and potassium. Potassium can be obtained from eating banana, but banana is also a taboo. By not eating banana she is reducing the amount of vitamin A, folic acid, iron, phosphorus, and calcium. Calcium could be obtained from catfishwhich is very abundant in the River Gambia-but it is also a taboo. Eggs are also a taboo, which leads to a decrease in the intake of calcium, iron, Vit A, proteins, or cholesterol. How can then a woman that does not eat catfish, bread, banana, and eggs and cannot afford to buy meat avoid animal protein and energy depletion during pregnancy?

Taboos during pregnancy and lactation play a crucial role to protein-caloric malnutrition (Figure 1). Pregnant mothers do not consume eggs, bread, bananas, catfish, or groundnut. Neither these foods nor any of the general food taboos mentioned or the ones related to the kabilah the mother belongs to. Hence, the diet of a pregnant woman is likely to be very poor in proteins and carbohydrates. The risk for the mother and the baby she is bearing is significant [3].

These cultural taboos are not exclusively found in The Gambia. Interestingly, eggs, fish, and bananas are also considered food taboos during pregnancy in other ethnic groups in Papua New Guinea and in Nigeria [14, 23]. The same types of foods can be observed as taboos in different contexts but in different life events. Eggs, for instance, are also a taboo for young girls in Lesotho, who are warned not to eat eggs, since it is believed that eggs increase the sexual desire in girls and lead them to seek out sexual relationships with boys [24]. While in Gambia pregnant women do not eat eggs fearing that the child will be mute or stuttering, coconut milk is not given to children in Benin, Nigeria, because it is believed that the milk will render them unintelligent [14]. Gambian women do not eat catfish during pregnancy, and Nigerian women do not eat snails for the same purpose to prevent giving birth to a dribbling baby [14].

Micronutrient consumption is also affected by these taboos. Non-timber forest products (NTFP) constitute an important component of household food consumption in SubSaharan Africa. These NTFP products have been identified in strategies to prevent micronutrient deficiencies. Some of the food taboos identified by the respondents (e.g., warthog, partridges, grasshoppers, termites, baobab) are available in the forests that surround their villages, but, since they are considered taboos in specific situations, they cannot be used to guarantee an appropriate nutrition [22].
The base of a Gambian lunch is a main course of staple (millet and rice, mainly) with a few spoons of stew over it. The stew is made out of groundnut paste, catfish, sorrel, okra and other locally gardened vegetables. Some of these ingredients are food taboos. The poorest families do not have access to meat every day. If they had, when serving the lunch, it is the men who have the best and largest share. In combination with other cultural factors and economic constraints, food taboos are only one more component that ends up impacting the health and nutrition of the most vulnerable ones [3]. It can thus be concluded that taboos must be considered one of the contributing factors to the high prevalence of underweight and wasted under-fives in The Gambia.

Regrettably, no other conclusions can be drawn from other common areas of knowledge. It cannot be concluded that belonging to certain kabilah can limit the access to food. According to the respondents, each kabilah has only one or two types of food they are not supposed to eat, which leaves a wide variety of food they can eat instead. And most of the respondents did not identify any food as taboo in their kabilah.

Eating food prepared by a non-circumcised woman cannot be considered as a factor limiting access to food. Because almost every Fulla woman has been circumcised in The Gambia [8], the chances of being offered food cooked by a non-circumcised woman are scarce. Refusing to consume food cooked by a non-circumcised woman is not a unique scenario in the cultural setting; it has also been reported among Somali immigrants in Sweden [25]. Besides, in this study, half of the respondents said that they would eat such food, which can imply a changing trend in modern Fulla society, more open to accepting the eating of food from other women regardless of whether they had undergone female genital mutilation or not.

4.2. The Impact of Health Education. Recent education interventions have promoted better nutrition-seeking behaviours in The Gambia $[3,12]$. Some of the food considered taboos during pregnancy, such as bread, banana, or eggs, are now consumed by many Fulla pregnant women, as a result of the efforts of health workers in reducing the incidence of malnutrition. The respondents remarked that they had gained more knowledge on nutrition thanks to these types of interventions. This implies that education is an effective tool to achieve behavioural changes concerning diet and nutrition. The most remarkable example of the success of this educational approach is that all the respondents said that they provide colostrum to the newborn.

Mothers and children are victims of an environment in which their nutrition and diet is largely regulated by ancient customs and taboos [18, 19]. Knowledge on food taboos can help understand the aetiology, therapy, and preventive aspects of the nutrition and health problems in any community. Not knowing the history and motivations behind the food taboos-for example, they should not eat warthog because it is forbidden by Islam-is one of the major bias to planning education strategies and other interventions for the proper improvement of the health status 
of the population $[14,22]$. Nutritional educational is one of the major interventions aimed at increasing dietary protein intake to improve growth and reduce morbidity in children and pregnant women [26]. Diet decision-makers can be taught on how to introduce some of these forbidden foods by learning their nutritional content, their benefits to children and maternal health, and coming up with ways of cooking them following their traditional recipes.

Finally, from the findings of this study, some recommendations for educational strategies on nutrition to the Fulla populations of The Gambia can be made.

(i) Analyse together with the population the origins, raison d'etre, benefits, and harms of their food taboos. For instance, it is interesting to note that some foods, such as banana or bread, are not eaten during pregnancy because it is believed that the baby will be too big and the labour will then be difficult. Among other reasons (lack of well-resourced network of primary health care centres, e.g.), mothers can be told that labour is difficult, long, and painful in circumcised women [8] and that anaemia and protein deficiencies during pregnancy can influence the delivery [27].

(ii) Insist on the importance of eating food rich in proteins and energy such as eggs, fish, bread, or groundnut during pregnancy.

(iii) Focus on designing, together with the decisionmakers of the Fulla families, mainly grandmothers [11, 12], diets for children and pregnant women that include food rich in all the essential nutrients.

(iv) Discuss the way they prepare their recipes and how they distribute the food among their family members and advocate for the introduction of changes that might benefit the most vulnerable-for example, put aside in a plate the portion the children should have before serving the men [14].

(v) Reinforce their knowledge on the importance of colostrum, exclusive breastfeeding, and the proper introduction of weaning foods [12].

To inform the design of educational interventions, it is recommended to further undertake a more comprehensive and in-depth analysis of how the cultural traditions and customs-including food taboos-influence the nutrition and health of pregnant mothers and children among the settled Fulla in The Gambia.

4.3. Bias Identified. The most relevant bias was the linguistic barrier. This was evidenced because the interviews were carried out in Fulla and then translated into English. The nurses who prepared the transcripts, who had been trained as interviewers, were not professional translators. Unidentified bias might have been introduced during the translation process.

Other important bias was to discuss what a taboo is for this specific cultural context with the respondents. Explanations of their food preferences or Islamic food prohibitions (e.g., bushpig or warthog) were at times given, rather than talking about the cultural taboos specifically related with their Fulla tradition. This bias was aimed to be minimized by explaining the respondents that they were not expected to explain the norms they had to observe during the time of Ramadam, a month in which Muslims fast and a radical change in diet and the quality of ingested nutrients occur for one lunar month [26]. Whenever it seemed obvious to the researchers that the respondent was talking from a religious or personal preferences point of view, her comments were not considered during analysis.

Ogbeide [14], on his study on food taboos in Mid-West Nigeria, explained that all the respondents were reluctant to provide detailed answers on the reasons of their taboos because they were suspicious of the actual researcher's intentions. For this study, it was attempted to minimize this risk during the selection and training of the interviewers and then during the pilot of the questionnaire. Nevertheless, the same phenomenon that Ogbeide experienced might have been the reason why some of the food taboos mentioned in this study remained insufficiently explained.

Other bias may have been that snowball sampling was the method used to recruit the respondents. There is controversy in whether snowball or purposive sampling better guarantees internal validity in qualitative studies [17]. However, the difference between snowball and purposive sample is very thin. In this study the interviewers were given flexibility to identify appropriate respondents that complied with the inclusion criteria but, especially, that were willing to speak openly about cultural taboos. To ensure the respondents' answers facilitated to meet the objective of the study, having one key informant leading the interviewer to the next key informant turned out being an effective sampling method.

\section{Conclusion}

A qualitative research in the URR, The Gambia, was carried out with the objective to learn about the food taboos among the Fulla that could contribute to the high prevalence of children and mother malnutrition in the region. Seventeen mothers participated in the study. According to the results, the Fulla refuse to eat several types of food rich in animal proteins during all their life stages and several types of food rich in carbohydrates, animal proteins, and micronutrients during pregnancy. These taboos must be considered a contributing factor to protein-caloric malnutrition during childhood and pregnancy.

If educational strategies are to be designed aimed at decreasing the prevalence of malnutrition in The Gambia, the food taboos have to be analysed together with the populations and especially with the household diet decision-makers. Advocacy for a behavioural change in diet habits through education on nutrition is to be considered one of the most essential tools.

Future research should focus on how educational strategies that address food taboos have an impact in terms of behavioural change regarding a high protein diet. Since most of the women were not aware of the origins of the food taboos, Fulla men should also be addressed and explore 
their knowledge, attitude, and perception towards the impact of these taboos in the nutrition of children and pregnant women.

\section{Conflict of Interests}

The authors declare that they do not have any conflict of interests.

\section{Acknowledgments}

The authors thank Philip Brookes for his helpful editing labour. They also thank Paula Bolea, Mariama Mendy, Metta Bah, and Sanna Jallow for their help in carrying out and transcribing the interviews. Thanks are due to NGO Nutrition Without Borders for their support at the Centre for Nutritional Rehabilitation and Education in Basse.

\section{References}

[1] S. Nandy, M. Irving, D. Gordon, S. V. Subramanian, and G. D. Smith, "Poverty, child undernutrition and morbidity: new evidence from India," Bulletin of the World Health Organization, vol. 83, no. 3, pp. 210-216, 2005.

[2] D. T. Goon, A. L. Toriola, B. S. Shaw et al., "Anthropometrically determined nutritional status of urban primary schoolchildren in Makurdi, Nigeria," BMC Public Health, vol. 11, p. 769, 2011.

[3] M. Mwangome, A. Prentice, E. Plugge, and C. Nweneka, "Determinants of appropriate child health and nutrition practices among women in rural Gambia," Journal of Health, Population and Nutrition, vol. 28, no. 2, pp. 167-172, 2010.

[4] Statoids, "Administrative division of countries: Gambia," http://www.statoids.com/ugm.html, 2013.

[5] United Nations development Program (UNDP), "Gambia: Country profile. Human Development Index," http://hdrstats .undp.org/es/paises/perfiles/GMB.html, 2013.

[6] United Nations Children's Fund (UNICEF), "At a glance: Gambia. Statistics," http://www.unicef.org/infobycountry/gambia statistics.html\#87, 2013.

[7] C. Hamer, K. Kvatum, D. Jeffries, and S. Allen, "Detection of severe protein-energy malnutrition by nurses in the Gambia," Archives of Disease in Childhood, vol. 89, no. 2, pp. 181-184, 2004.

[8] A. Kaplan Marcusán, S. Hechavarría Toledo, and N. L. Puppo Avila, Manual on Female Genital Mutilation/Cutting for Health Professionals, Interdisciplinary Group for the Prevention and Study of Harmful Traditional Practices, UAB and Wassu Kafo Gambia, Banjul, Gambia, 2010.

[9] U. F. Ekpo, A. M. Omotayo, and M. A. Dipeolu, "Changing lifestyle and prevalence of malnutrition among settled pastoral Fulani children in Southwest Nigeria," Annals of Agricultural and Environmental Medicine, vol. 15, no. 2, pp. 187-191, 2008.

[10] A. Abubakar, P. Holding, M. Mwangome, and K. Maitland, "Maternal perceptions of factors contributing to severe undernutrition among children in a rural African setting," Rural and Remote Health, vol. 11, no. 1, pp. 1423-1433, 2011.

[11] R. Sear, R. Mace, and I. A. McGregor, "Maternal grandmothers improve nutritional status and survival of children in rural Gambia," Proceedings of the Royal Society B, vol. 267, no. 1453, pp. 1641-1647, 2000.
[12] I. J. Semega-Janneh, E. Bøhler, H. Holm, I. Matheson, and G. Holmboe-Ottesen, "Promoting breastfeeding in rural Gambia: combining traditional and modern knowledge," Health Policy and Planning, vol. 16, no. 2, pp. 199-205, 2001.

[13] UNICEF, Strategy for Improved Nutrition of Children and Women in Developing Countries, UNICEF, New York, NY, USA, 1990.

[14] O. Ogbeide, "Nutritional hazards of food taboos and preferences in Mid-West Nigeria," American Journal of Clinical Nutrition, vol. 27, no. 2, pp. 213-216, 1974.

[15] United Nations Department of Economic and Social Affairs, Designing Household Survey Samples: Practical Guidelines, United Nations, New York, NY, USA, 2005.

[16] M. A. Whaling, I. Luginaah, G. Reid et al., "Perceptions about probiotic yogurt for health and nutrition in the context of HIV/AIDS in Mwanza, Tanzania," Journal of Health, Population and Nutrition, vol. 30, no. 1, pp. 31-40, 2012.

[17] C. A. Sandoval Casilimas, Investigación Cualitativa, ICFES, Bogotá, Colombia, 1996.

[18] O. O. Ajayi, "Taboos and clinical research in West Africa," Journal of Medical Ethics, vol. 6, no. 2, pp. 61-63, 1980.

[19] A. Ahenkan and E. Boon, "Improving nutrition and health through non-timber forest products in Ghana," Journal of Health, Population and Nutrition, vol. 29, no. 2, pp. 141-148, 2011.

[20] A. Van Huis, J. Van Itterbeeck, H. Klunder et al., "Edible insects: future prospects for food and feed security," FAO Forestry Paper 171, 2013.

[21] Food and Agriculture Organization (FAO) and World Health Organization (WHO), "Living well with HIV/AIDS. A manual on nutritional care and support for people living with HIV/ AIDS," http://www.fao.org/DOCREP/005/Y4168E/Y4168E00 .HTM, 2002.

[22] K. Stephenson, R. Amthor, S. Mallowa et al., "Consuming cassava as a staple food places children 2-5 years old at risk for inadequate protein intake, an observational study in Kenya and Nigeria," Nutrition Journal, vol. 9, no. 1, p. 9, 2010.

[23] V. B. Meyer-Rochow, "Food taboos: their origins and purposes," Journal of Ethnobiology and Ethnomedicine, vol. 5, p. 18, 2009.

[24] J. Gay, "Mummies and babies' and friends and lovers in Lesotho," in Anthropology and Homosexual Behaviour, E. Blackwood, Ed., Haworth Press, London, UK, 1986.

[25] B. M. Ahlberg, I. Krantz, G. Lindmark, and M. Warsame, "Its only a tradition': making sense of eradication interventions and the persistence of female 'circumcision' within a Swedish context," Critical Social Policy, vol. 24, no. 1, pp. 50-78, 2004.

[26] M. Y. Lamri-Senhadji, B. El Kebir, J. Belleville, and M. Bouchenak, "Assessment of dietary consumption and timecourse of changes in serum lipids and lipoproteins before, during and after Ramadan in young Algerian adults," Singapore Medical Journal, vol. 50, no. 3, pp. 288-294, 2009.

[27] D. Rush, "Nutrition and maternal mortality in the developing world," American Journal of Clinical Nutrition, vol. 72, supplement 1, pp. 212S-240S, 2000. 

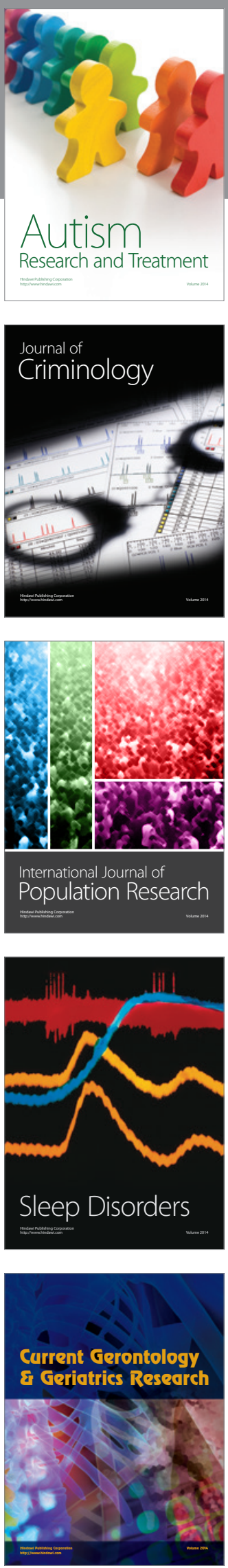
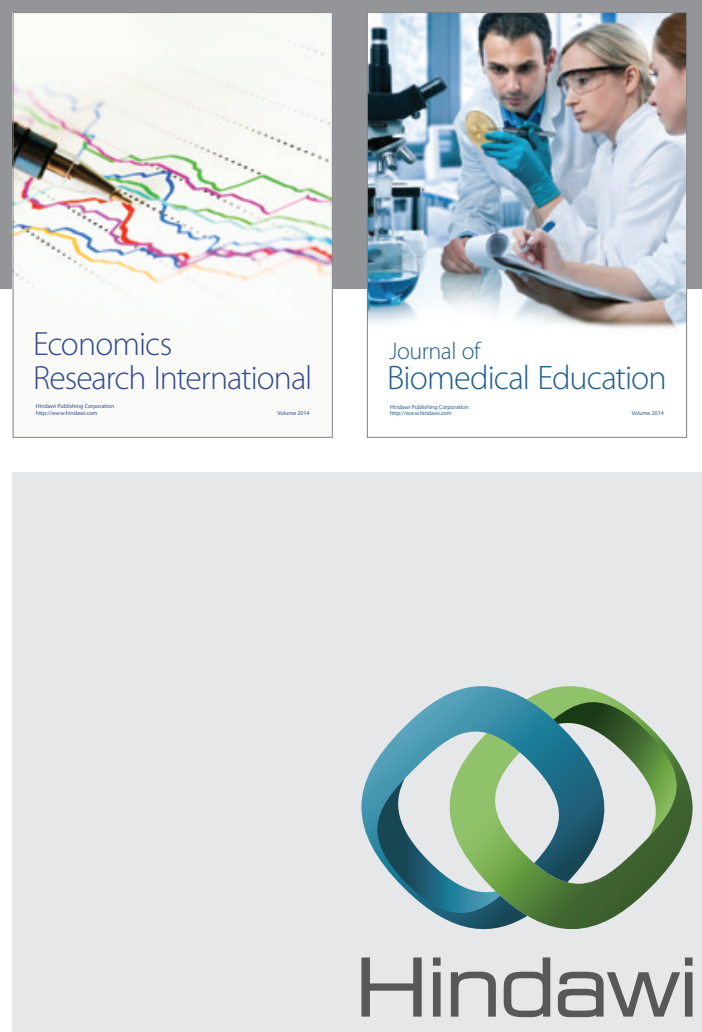

Submit your manuscripts at

http://www.hindawi.com
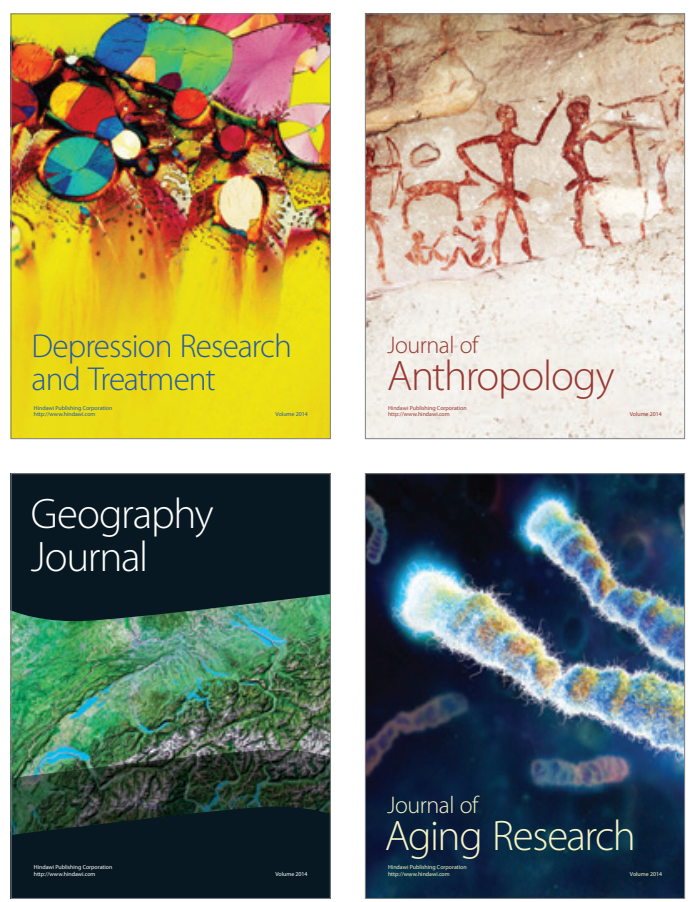
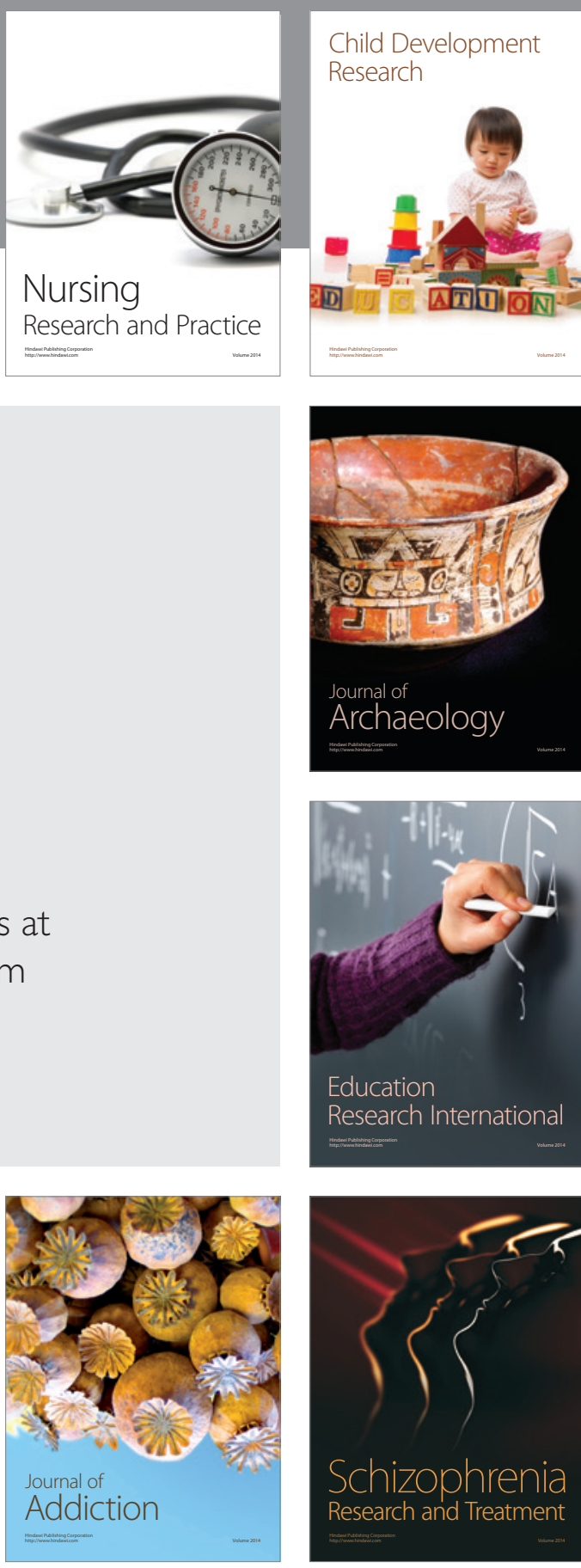

(D)
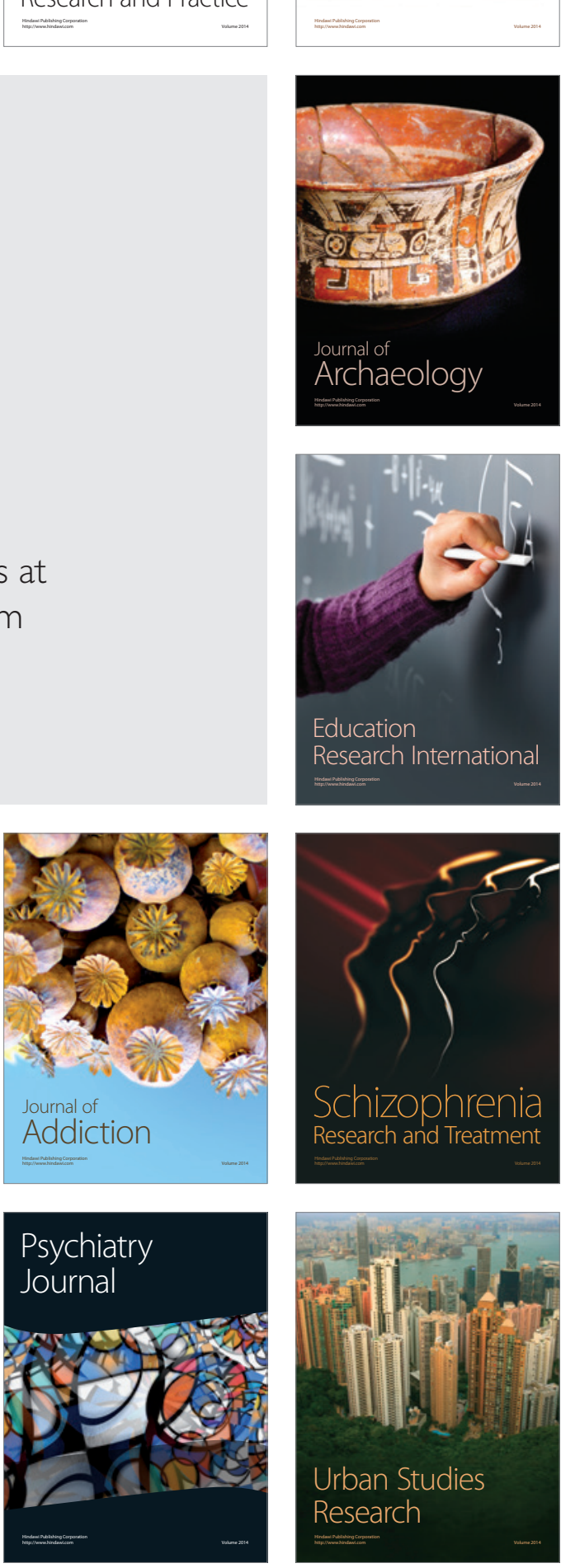